\title{
広領域地下水からの最適井戸取水について* \\ ON THE OPTIMAL WELL DISCHARGE IN GROUND WATER AREA
}

\author{
上田年比古** • 神 野 健 二*** ・ 長 野 益 徳**** \\ By Toshihiko UEDA, Kenji JINNO and Yoshinori CHYONO
}

\section{1. まえがき}

近年, 水資源の不足により地下水の有効利用が唱えら れているが，現実には必ずしも地域全体での地下水利用 が効率よく行われているとはいえないようで，一部では 過鄱揚水に伴ら地盤沈下や海岸部の地下水の塩水化など の揚水障害が発生している．揚水障害は長い年月にわた って徐々に進行することから, 広域的見地から十分な検 討のもとに合理的な取水計画を定めることが要請され， この決定法の確立はきわめて重要なことといえよう。こ の決定について, 従来は基礎式となる浸透流関する Laplace の方程式を，そのまま差分化してその地域内の 各井戸について種々揚水量を想定し，数值計算を繰返し 適切な水頭分布を与える揚水量を求めて，これを計画揚 水量とする方法がとられているよらである.しかし，こ の方法では領域あるいは揚水の条件が複雑な場合には， その最適な揚水計画をうること注困難と考えられ, 最適 化の手法が要請される.

さて近年, 地下水流の基礎式である Laplace の方程 式の離散式が線形であることから，これと線形計画法を 組み合わせて, 地下水関する最適化問題を解く研究が 行われている.すなわち，E. Aquardo および I. Remson は比較的抽象化された問題を取扱い，まず被圧ある いは不圧の与えられた領域内の 2 個以上の井戸の掦水総 量が指定值以上の範囲で，井戸水頭の合計最大に対する 各井戸の揚水量の決定 ${ }^{1}$ を行い，また，基礎掘削の工事 区域内の地下水位を，区域周辺に配置された井戸の揚水 により, 所要值以下に低下させる場合, 揚水総量最小の 各井戸の揚水量配分の決定 ${ }^{2), 3)}$ などを行っている.ま

* 土木学会第 32 回年次講演会, 水資源に関するシンポジウ 么（昭 52.10）にて一部発表

** 正会員 工博 九州大学教授 工学部水工土木学教室

*** 正会員 工修 九州大学助手 工学部水工士木学教室 **** 学生会員 九州大学大学院水工士木学専攻修士課程
た，佐藤・渡辺 ${ }^{4) ~ 6) ~}($ 埼玉地域を数個の地区に分割し， 各地区の揚水量と地盤沈下量の実測記録を用いて, 各地 区について地盤沈下に対する許容揚水量を設定し，また 総揚水量を与え, これらの制限のもとに各地区の地盤沈 下量の合計が最小になるような各井戸の揚水量を最適取 水量と定義して最適解を求めている. これらの研究にも みられるように, 地下水の最適取水の問題は, その最適 の考え方および実際問題への適用過程において種々の場 合が考えられ，まだ多くの問題が残されているようであ る.

本報は, まず地下水揚水場の数值計算の手法として, 複雑な境界形状に対して有利であること, および領域が 広く, また領域内の地質構造が複雑に変化する場合に比 較的少ない節点数でこれに対応できることなどから，こ こでは有限要素法を用い，これによって地下水頭から取 水量を算定する式形を導いた. 次に, この式を用いて広 域の地下水領域に分散配置された制御対象の井戸からの 定常取水について，地域内の揚水障害を防御し，そして 各制御井戸に課せられた水需要量をみたすという条件の もとでの最適取水について線形計画法による算定法をの べ，ついでこれを熊本平野西部の地下水領域に適用した 結果をのべ，終りに種々の条件のもとでの最適取水につ いてまとめて考察を加えたものである.

\section{2. 有限要素法による井戸揚水場の基礎式の離 散化}

ここでは数值計算手法として, 有限要素法を用いて解 析を進めよう。

\section{（1）境界条件}

図一1に示すような通常考えられる地下水領域に対す る 2 種類の境界条件として次のように与える.

(i) 境界 $\mathrm{B}_{1}, \mathrm{~B}_{2}$ は水頭 $h$ が既知であるとし， 


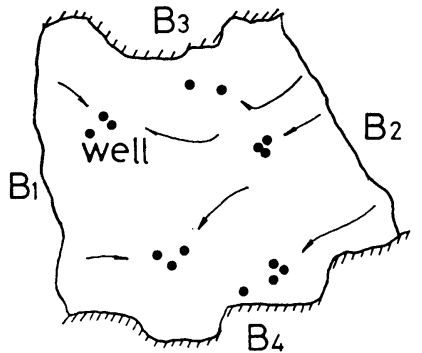

図一1 地下水領域モデル ( $\mathrm{B}_{1} \sim \mathrm{B}_{4}$ は境界 $)$

$h=H_{1}$ on $\mathrm{B}_{1}$ および $h=H_{2}$ on $\mathrm{B}_{2}$

(ii) 境界 $\mathrm{B}_{3}, \mathrm{~B}_{4}$ は不透水壁であるとし, $\partial h / \partial n=0$ on $\mathrm{B}_{3}, \mathrm{~B}_{4}$ （ $n$ は境界の法線方向）

\section{（2）井戸の取扱いおよび三角形要素の分割}

領域を三角形要素に分割するにあたり，まず井戸を， 本報で最適取水計画の対象とする制御井戸と，一般には 民家の井戸，農業用井戸などで制御の対象とせず取水量 一定とする非制御井戸とに分け，制御井戸を節点にと る. 制御井戸が 図一2のように群をなして集中している 場合には，その中央付近に 1 つの井戸を想定し，これを 節点にとる. 次に非制御井戸については，その個数も多 くなることから三角形要素を組むことにはその配置は特 に考慮せずに，三角形要素内に含めることにする．

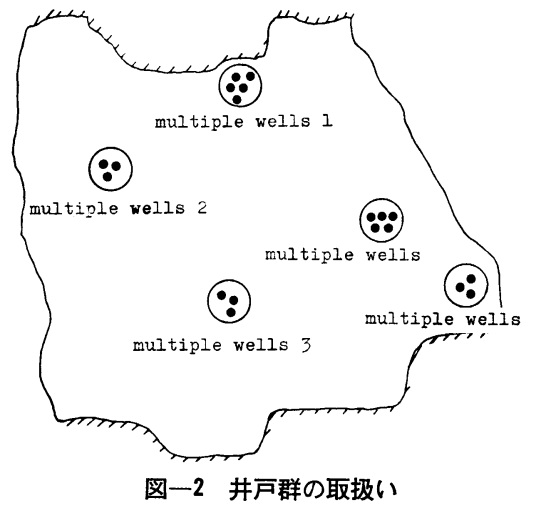

井戸をこのように取扱い，また境界形状，地盤地質を 考慮して領域を三角形要素に組み，その節点番号を次の 要領でつける. すなわち, (1) 制御井戸 ( $M$ 個) に節点 番号の始めから $1,2, \cdots, M$ の通し番号をつけ, 次に, (2) $M+1, M+2, \cdots$ の番号を制御井戸および境界 $\mathrm{B}_{1}$, $\mathrm{B}_{2}$ 上の節点を除いた一般の領域内の節点につけ, つい で, (3) 終りの方の通し番号を境界 $\mathrm{B}_{1}, \mathrm{~B}_{2}$ 上の節点につ ける.

\section{（3）基礎式とその離散化}

定常状態の地下水流の基礎式は Darcy 則が成り立つ
とすれば, 被圧地下水の場合,

$$
\begin{aligned}
& \partial(k b \partial h / \partial x) / \partial x+\partial(k b \partial h / \partial y) / \partial y \\
& \quad=\sum_{p} Q_{p} \delta\left(x-x_{p}\right) \delta\left(y-y_{p}\right)+R(x, y)
\end{aligned}
$$

不圧地下水の場合で準一様流の仮定が成り立つものとす れば,

$$
\begin{aligned}
& \partial(k h \partial h / \partial x) / \partial x+\partial(k h \partial h / \partial y) / \partial y \\
& \quad=\sum_{p} Q_{p} \delta\left(x-x_{p}\right) \delta\left(y-y_{p}\right)+R(x, y)
\end{aligned}
$$

この式を変形すると，

$$
\begin{aligned}
& \partial\left\{(k / 2) \partial h^{2} / \partial x\right\} \partial x+\partial\left\{(k / 2) \partial h^{2} / \partial y\right\} / \partial y \\
& =\sum_{p} Q_{p^{\delta}}\left(x-x_{p}\right)^{\delta}\left(y-y_{p}\right) \\
& \quad+R(x, y) \ldots \ldots \ldots \ldots \ldots \ldots \ldots \ldots \ldots \ldots \ldots \ldots \ldots \ldots \ldots \ldots \ldots \ldots
\end{aligned}
$$

ここに, $h$ : 被圧地下水では地下水の水頭, 不圧地下水 では不透水層からの地下水の水哚, $b$ : 被圧帯水層の厚 さ, $k$ : 透水係数, $Q_{p}$ : 井戸 $p$ (制御井戸および非制御 井戸のうちでその位置と揚水量がわかっている比較的大 きな井戸 [これを非制御大井戸とよんでおく]）の取水 量, $\delta(x), \delta(y)$ : デルタ関数, $\left(x_{p}, y_{p}\right)$ : 井戸 $p$ の, $y$ 座標, $R(x, y)$ : 帯水層の単位面積, 単位時間あたり の流出入量で, 外部への流出を十とする. これは帯水層 が不圧地下水では雨水の浸透追加, 被圧地下水では上層 不圧地下水からの浸透追加などであるが，ここではその 位置および揚水量のはっきりしない民家, 農業用の小規 模の井戸（これを非制御小井戸とよんで㧍く）の揚水量 もこれに含めることにする.

なお基礎式 (4) は， $h^{2} / 2$ を改めて $H$ とおくと本質 的には被圧地下水流の基礎式 (3) と同形であるので, 以 下においては式 (3) について検討を進めることにする.

式 (3) に対応する汎関数は ${ }^{7}$,

$$
\begin{aligned}
\chi(h)= & (1 / 2) \iint k b\left[(\partial h / \partial x)^{2}+(\partial h / \partial y)^{2}\right] d x d y \\
& +\iint\left[\sum_{p} Q_{p} \delta\left(x-x_{p}\right) \delta\left(y-y_{p}\right)\right] h d x d y \\
& +\iint R(x, y) h d x d y \cdots \cdots \cdots \cdots \cdots \cdots(5)
\end{aligned}
$$

いま, 図一3 に示す三角形要素 $e$ 内 で水頭 $h$ の一次分布を仮定すると $e$ 内の水頭 $h^{e}$ は節点の水頭を $h_{i}$, $h_{j}, h_{k}$ とすれば,

$$
h^{e}=N_{i} h_{i}+N_{j} h_{j}+N_{k} h_{k}
$$

ここに, $N_{i}(x, y)=a_{i}+b_{i} x+c_{i} y$,

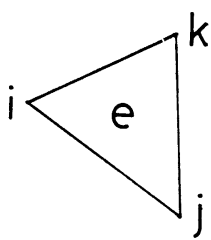

図一3 $a_{i}=x_{j} y_{k}-x_{k} y_{j}, \quad b_{i}=y_{j}-y_{k}, \quad c_{i}$ 三角形要素 $\boldsymbol{e}$ $=x_{k}-x_{j}, \cdots$, また, $x_{i}, y_{i}$ などは節点の $x, y$ 座標 である. 式 (6) を用いて, 式 (5) の $h_{i}$ についての変 分 $\partial \chi / \partial h_{i}$ をとり 0 とおけば節点の水頭 $h_{i}$ を末知数と する連立方程式が得られる. なお式 (5) 右辺第 2 項の 
井戸に関する項 $\left(\chi_{w}\right.$ とお

く)の三角形要素 $e$ につい

ての変分は次のようにな

る.いま, 図一4のように 非制御大井戸 $p^{\prime}$ (位置を $x_{p^{\prime}}, y_{p^{\prime}}$, 揚水量を $Q_{p^{\prime}}$ と

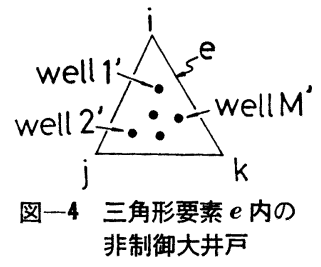

する) が要素 $e$ 内に $M^{\prime}$ 個含まれているとすれば,

$$
\begin{aligned}
& \partial y_{w}{ }^{e} / \partial h_{i}=\iint_{p^{\prime}=1}^{M^{\prime}} Q_{p^{\prime}}\left(x-x_{p^{\prime}}\right) \delta\left(y-y_{p^{\prime}}\right) \\
& \text { - } N_{i}(x, y) d x d y \text {. }
\end{aligned}
$$

$f(x, y)$ を連続関数とするとき, デルタ関数の性質か ら,

$$
\begin{aligned}
& \iint f(x, y) \delta\left(x-x_{p^{\prime}}\right) \delta\left(y-y_{p^{\prime}}\right) d x d y \\
& \quad=f\left(x_{p^{\prime}}, y_{p^{\prime}}\right)
\end{aligned}
$$

となるので8)，これを用いると式 (7) は,

$$
\partial \chi_{w}{ }^{e} / \partial h_{i}=\sum_{p^{\prime}=1}^{M^{\prime}} Q_{p^{\prime}} N_{i}\left(x_{p^{\prime}}, y_{p^{\prime}}\right) .
$$

となる. 同様にして揚水量 $Q_{p}$ の制御井戸が節点 $i$ に おかれている場合は，

$$
\partial x_{w}{ }^{e} / \partial h_{i}=Q_{p} N_{i}\left(x_{i}, y_{i}\right)=Q_{p} \cdots
$$

また, $i$ 以外の節点, たとえば $j$ にかかれてる場合 は,

$$
\partial x_{w}{ }^{e} / \partial h_{i}=Q_{p} N_{i}\left(x_{j}, y_{j}\right)=0 .
$$

これらが前述の連立方程式に含まれることになる.

次に非制御小井戸については，領域の単位面積当りの 帯水層からの流出量として式 (5) 右辺第 3 項の $R(x, y)$ に含めることにする.

このようにして得られた節点の水頭についての連立方 程式をマトリックス表示すると, 次のよらに表わされ る.

$$
\boldsymbol{A h}=\boldsymbol{F Q}+\boldsymbol{R}
$$

ここに, $\boldsymbol{A}$ : 透水量係数と節点座標よりなる係数行列, $\boldsymbol{h}:$ 節点の水頭ベクトル, $\boldsymbol{F}$ : 節点座標および非制御大 井戸の座標よりなる係数行列, $\boldsymbol{Q}$ : 揚水量ベクトル, $\boldsymbol{R}$ : 帯水層からの流出入量に対応寸る定数項 ベクトルであ る.

式（11）を次のように小行列に分割する.

$$
\begin{aligned}
& {\left[\begin{array}{lll}
\boldsymbol{A}_{11} & \boldsymbol{A}_{12} & \boldsymbol{A}_{13} \\
\boldsymbol{A}_{21} & \boldsymbol{A}_{22} & \boldsymbol{A}_{23} \\
\boldsymbol{A}_{31} & \boldsymbol{A}_{32} & \boldsymbol{A}_{33}
\end{array}\right]\left[\begin{array}{l}
\boldsymbol{h}_{w} \\
\boldsymbol{h}_{r} \\
\boldsymbol{h}_{b}
\end{array}\right]} \\
& =\left[\begin{array}{lll}
\boldsymbol{F}_{11} & \boldsymbol{F}_{12} & \boldsymbol{F}_{13} \\
\boldsymbol{F}_{21} & \boldsymbol{F}_{22} & \boldsymbol{F}_{23} \\
\boldsymbol{F}_{31} & \boldsymbol{F}_{32} & \boldsymbol{F}_{33}
\end{array}\right]\left[\begin{array}{l}
\boldsymbol{Q}_{w} \\
\boldsymbol{Q}_{r} \\
\boldsymbol{Q}_{b}
\end{array}\right]+\left[\begin{array}{l}
\boldsymbol{R}_{1} \\
\boldsymbol{R}_{2} \\
\boldsymbol{R}_{3}
\end{array}\right]
\end{aligned}
$$

この小行列は, 制御井戸の節点（節点番号 $1 \sim \mathrm{M}$ ） と 一般の節点（節点番号 $\mathrm{M}+1 \sim$ ）および境界 $\mathrm{B}_{1}, \mathrm{~B}_{2}$ 上 の節点 (終りの節点番号) の 3 グループに分割したもの である. $\boldsymbol{h}_{w}$ 浪制御井戸の節点の水頭, $\boldsymbol{h}_{b}$ は境界 $\mathrm{B}_{1}$,
$\mathrm{B}_{2}$ 上の節点の水頭, $\boldsymbol{h}_{r}$ は残りの一般の節点の水頭であ る. $\boldsymbol{Q}_{w}$ は制御井戸の取水量, $\boldsymbol{Q}_{r}, \boldsymbol{Q}_{b}$ は非制御大井戸 の取水量である.なお，ここでは境界上には井戸がない ので $\boldsymbol{Q}_{b}=\mathbf{0}$ である. 式 (12) において $\boldsymbol{Q}_{\boldsymbol{w}}$ が与えられ れば， $\boldsymbol{h}_{b}, \boldsymbol{Q}_{r}, \boldsymbol{Q}_{b}$ は既知であるので領域内の水頭分布 $\left(\boldsymbol{h}_{w}, \boldsymbol{h}_{r}\right)$ が式 (12) の初めの 2 式より求められる.す なわち, 式 (12) は領域の境界条件と井戸の揚水量を与 えて，領域内の水頭を求める式である.

\section{（4）井戸水頭之井戸取水量の関係式}

式（12）を変形して制御井戸の水頭 $\boldsymbol{h}_{\boldsymbol{w}}$ を与えて制御 井戸の取水量 $\boldsymbol{Q}_{w}$ を求める式になおそう.この場合末知 数は $\boldsymbol{Q}_{w}, \boldsymbol{h}_{r}$, 既知数は $\boldsymbol{h}_{w}, \boldsymbol{h}_{b}, \boldsymbol{Q}_{r}, \boldsymbol{Q}_{b}(=\mathbf{0})$ および $\boldsymbol{R}$ であるので, 式（12）の初めの 2 式より $\boldsymbol{h}_{\boldsymbol{r}}$ を消去する と,

$$
\begin{aligned}
{\left[\boldsymbol{F}_{11}-\boldsymbol{A}_{12} \boldsymbol{A}_{22}{ }^{-1} \boldsymbol{F}_{21}\right] \boldsymbol{Q}_{w} } \\
=\left[\boldsymbol{A}_{11}-\boldsymbol{A}_{12} \boldsymbol{A}_{22}{ }^{-1} \boldsymbol{A}_{21}\right] h_{w}+\left[\boldsymbol{A}_{12} \boldsymbol{A}_{22}{ }^{-1} \boldsymbol{F}_{22}-\boldsymbol{F}_{12}\right] \\
\quad \boldsymbol{Q}_{r}+\left[\boldsymbol{A}_{13}-\boldsymbol{A}_{12} \boldsymbol{A}_{22}{ }^{-1} \boldsymbol{A}_{23}\right] \boldsymbol{h}_{b} \\
\quad+\left[\boldsymbol{A}_{12} \boldsymbol{A}_{22}{ }^{-1} \boldsymbol{R}_{2}-\boldsymbol{R}_{1}\right] \ldots \ldots \ldots \ldots \ldots \ldots \ldots(13)
\end{aligned}
$$

すなわち求める制御井戸の取水量 $\mathbf{Q}_{\boldsymbol{w}}$ は,

$$
\mathbf{Q}_{w}=\boldsymbol{P} \boldsymbol{h}_{w}+\boldsymbol{q}
$$

ここに,

$$
\begin{aligned}
& \boldsymbol{P}= {\left[\boldsymbol{F}_{11}-\boldsymbol{A}_{12} \boldsymbol{A}_{22}{ }^{-1} \boldsymbol{F}_{21}\right]^{-1}\left[\boldsymbol{A}_{11}-\boldsymbol{A}_{12} \boldsymbol{A}_{22}{ }^{-1} \boldsymbol{A}_{21}\right] } \\
& \ldots \ldots \ldots \ldots \ldots \ldots(15) \\
& \boldsymbol{q}= {\left[\boldsymbol{F}_{11}-\boldsymbol{A}_{12} \boldsymbol{A}_{22}{ }^{-1} \boldsymbol{F}_{21}\right]^{-1}\left\{\left[\boldsymbol{A}_{12}-\boldsymbol{A}_{22}{ }^{-1} \boldsymbol{F}_{22}-\boldsymbol{F}_{12}\right] \boldsymbol{Q}_{r}\right.} \\
&+\left[\boldsymbol{A}_{13}-\boldsymbol{A}_{12} \boldsymbol{A}_{22}{ }^{-1} \boldsymbol{A}_{23}\right] \boldsymbol{h}_{b} \\
&\left.+\left[\boldsymbol{A}_{12} \boldsymbol{A}_{22}{ }^{-1} \boldsymbol{R}_{2}-\boldsymbol{R}_{1}\right]\right\} \cdots \cdots \cdots \cdots \cdots \cdots \cdots(16)
\end{aligned}
$$

式 (14) の係数行列 $\boldsymbol{P}$ と列ベクトル $\boldsymbol{q}$ は後で検討す るように対象地域の境界条件, 地盤地質条件および井戸 の大きさとその配置の関数であり, その地域の揚水に関 する特性量を示すものである（なお，後述では $\boldsymbol{q}$ の代り にこれを変形した $\boldsymbol{P}_{0}$ について検討している). したが って, 従来までの広域の地下水場の解析では, さきに述 べたように与えられた各井戸の揚水量に対して領域内の 水頭分布を数值計算する段階でとどまっていたが, 式 （14）の式形にすることによって取水計画にあたっての 基礎的資料と考えられる $\boldsymbol{P}, \boldsymbol{q}$ を取り出すことができた ものと考える.

\section{3. 取水計画にあたっての基本的な解}

\section{（1）井戸の低限界水頭と水需要量}

地下水の過㮃揚水に伴う障害として地盤沈下や海水の 内陸部への侵入による地下水の塩水化などがあげられて いる.これらの防止策として，揚水量を規制するか，水 頭低下を規制するかは異論のあるところである。「水道 
施設設計指針・解説」9)では, 一つの井戸について揚水 試験による限界揚水量の $70 \%$ 以下を「適正な揚水量」 とし，また，地下水域の水収支の均衡を崩さず長期的に 揚水できる揚水量を「安全場水量」と定義して, これら の揚水量で揚水することが求められている ${ }^{10)}$. しかし， 一方, 地盤沈下浽带水層内の間隚水圧の低下が原因と考 えられていて, 地盤沈下量 $\Delta b^{\prime}$ は $\Delta h$ を水頭の低下量, $b^{\prime}$ を沈下地盤の層厚, $m_{v}$ を地盤の压縮倸数， $r_{w}$ を水 の単位体積重量とすれば,

$$
\Delta b^{\prime}=m_{v} r_{w} b^{\prime} \Delta h
$$

で示されている ${ }^{10)}$. また, 海水の内陸部への地下侵入も 水圧の関係で発生する現象と考えられる。したがって, 揚水量は規制対象として現実的には取扱いやすいがあく まで間接的なものと考えられ，ここでは揚水障害の直接 的原因は地下水の水頭の異常低下として, これ以下に水 頭が下がると揚水障害が発生すると考えられる低限界の 水頭值を「低限界水頭」と定義する。 な㧍，式（17）で は水頭の低下 $\Delta h$ が生じると必ず沈下が発生することに なるので，沈下量に対して許容値を与えてそれに対する $\Delta h$ からこの低限界水頭を設定することにならら。また， 佐藤・渡边 ${ }^{4}$ ( 埼玉県下の地盤沈下の資料から沈下を生 じない揚水量が存在することを指摘している.したがっ て低限界水頭の設定が可能であると考えてよいである う。また，海岸部については，たとえば地下塩水楔の許 容侵入限界を設定して，これに対する低限界水頭を考え ることができよう。

次に，井戸揚水場では，水頭低下のもっとも大きいの は井戸水位であるので，ここでは制御井戸の水位にこの 低限界水頭（これを $\boldsymbol{h}_{w}$ *とする）を設定し，この水頭 より低下しないように揚水量の制御をすることにした。 なお制御井戸以外で揚水障害が問題となる場所たとえば 非制御井戸地点あるいは地盤沈下の生じやすい䇢所があ る場合には, 式 (14)〜 (16) の代りにその井戸または地 点の水頭と制御井戸の揚水量との関係式を導き，以下の 検討を同様にして進めればよいと考える.

次に，制御井戸について，その井戸の配水区域の水需 要量の推定を行ってこれを $\mathbf{Q}_{w}{ }^{*}$ とする.

\section{（2）低限界水頭と水需要量の条件を満たし域内取水 量を最大にする解}

ここでは, 各制御井戸の水頭がその低限界水頭以上と いう条件と，少なくともその井戸の水需要量を取水する といら条件のもとに, 領域の総取水量を最大にする場合 の各井戸の取水量を最適值問題として解いてみよう。こ こで取扱う地下水場は，降雨や上部帯水層からの非定常 な漏水追加，地下水源としての河川，湖沼の水位あるい は地下水領域境界の水位の非定常な変動，あるいは現実
的には必ずしも定常的な取水が行われていないことなど を考えれば, 非定常状態での解析を考えるべきであるが 広域的な地域固有の特性の把握および地下水取水計画作 成の基礎的資料をらる目的から，ここでは定常状態につ いて解析を行った. したがって,この解析には定常状態 を対象にした線形計画法を適用することにする.

a) 基 礎 式

いま，低限界水頭から上に測った水頭，

$$
\boldsymbol{h}_{w}{ }^{\prime}=\boldsymbol{h}_{w}-\boldsymbol{h}_{w}{ }^{*}
$$

を新しい変数とすれば式 (14) は，

$$
\begin{aligned}
& \boldsymbol{Q}_{w}=\boldsymbol{P h}^{\prime}{ }_{w}+\left(\boldsymbol{P} \boldsymbol{h}_{w}{ }^{*}+\boldsymbol{q}\right)=\boldsymbol{P} \boldsymbol{h}_{w}{ }^{\prime}+\boldsymbol{P}_{0} \\
& \text { ここた, } \\
& \boldsymbol{P}_{0}=\boldsymbol{P h}_{w}{ }^{*}+\boldsymbol{q}
\end{aligned}
$$

また，制御井戸 $m$ の取水量 $Q_{m}$ ( $\boldsymbol{Q}_{w}$ の成分值）の合計 を

$$
g=\sum_{m=1}^{M} Q_{m}
$$

とすれば,この問題は,

$$
\mathbf{Q}_{w} \geqq \boldsymbol{Q}_{w^{*}}{ }^{\prime}, \quad \boldsymbol{h}_{w}{ }^{\prime} \geqq \mathbf{0}
$$

の制約のもとで，評価関数 $g$ を最大にする問題となり， 線形計画法 ${ }^{11}$ により解を求めることができる。ここに，

$$
\begin{aligned}
g & =\sum_{m=1}^{M} Q_{m}=\sum_{m=1}^{M}\left(\sum_{l=1}^{M} P_{m l} h_{l}\right)+\sum_{m=1}^{M} P_{0 m} \\
& =\sum_{l=1}^{M}\left\{\left(\sum_{m=1}^{M} P_{m l}\right) \cdot h_{l}\right\}+\sum_{m=1}^{M} P_{0 m} \\
& =\sum_{l=1}^{M}\left(u_{l} \cdot h_{l}^{\prime}\right)+G \ldots \ldots \ldots \ldots \ldots \ldots \ldots \ldots \ldots \ldots \ldots \ldots \ldots \ldots \ldots \ldots
\end{aligned}
$$

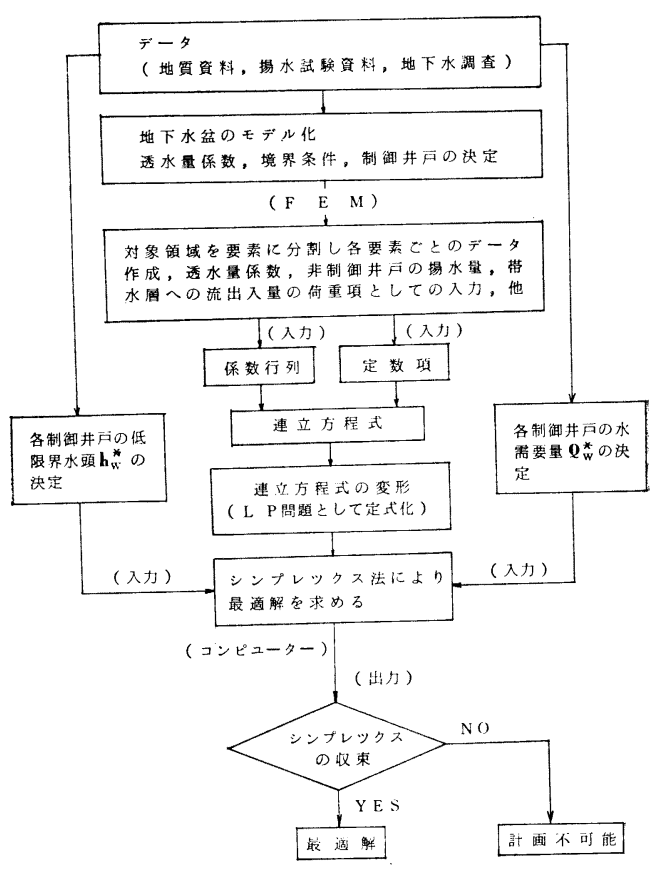

図一5 2 条件を㴖たし, 総取水量最大の解のフローチャート 


$$
u_{l}=\sum_{m=1}^{M} P_{m l}, \quad G=\sum_{m=1}^{M} P_{0 m}
$$

ただし， $m$ または $l$ は制御井戸の番号で, $P_{m l}, P_{0 m}$ は 行列 $\boldsymbol{P}$ (対称行列) および列べクトル $\boldsymbol{P}_{0}$ の成分であ り， $h_{l}^{\prime}(l=1,2, \cdots, M)$ は列ベクトル $\boldsymbol{h}_{w}^{\prime}$ の成分であ る. 以上の計算のフローチャートを図一5 に示してい る.

また，上述の 2 条件を満たしたらえで，ある特定の制 御井戸 $m_{s}$ の取水量をできるだけ大きくしたい場合に は, 式 (21) の代りに評価関数,

$$
g_{s}=\sum_{m_{s}} Q_{m_{s}} \Rightarrow \max
$$

を用いて同様の算定を行えばこの場合の各制御井戸の取 水量を求めることができよう.

なお以下の適用例においては式（21）による解につい て述べる。

\section{b) 適用例}

（i） 適用領域の概要と境界条件

ここでは熊本市水道局の報告書 ${ }^{12)}$ で，取水計画につい て検討されている図一6に示すような熊本平野西部の海 岸に至る面積約 $210 \mathrm{~km}^{2}$ の地域の被圧带水層に 適用す る. なお，この適用例においては水頭 $h$ は標高 $(\mathrm{m})$ を 用いる. この地域は全量地下水依存の熊本市上水道の水 源の一部であり, 現在地盤沈下や地下水の塩水化の進行 が観測されていて，この揚水障害は同市の上水道計画に 重大な影響を与えるものとされている。 また，図一6の $\mathrm{AA}^{\prime}$ 線にそう縦断方向の地層分布図を図一7に示して いる. 図の $D_{s}$ (島原海湾層), $A_{s 0}-4$ および $D_{c g}$ (未 区分洪積層）が取水対象の被圧帯水層である.この地域 は図一6に示すように，南側は第三系からなる山地を境

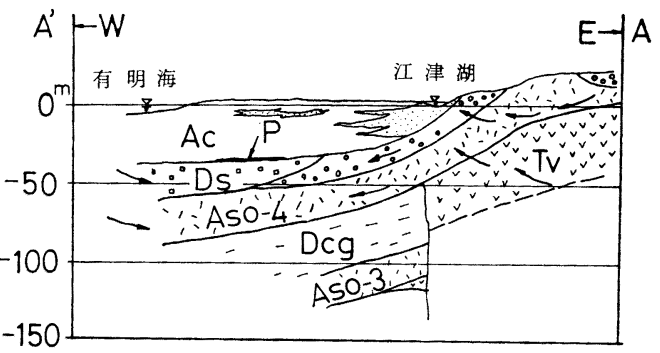

$\mathrm{Ac}$ : 有明粘土層, Ds : 島原海湾層, Dcg : 未区分 洪積層, Tv : 砥川溶岩, Aso-3, Aso-4 : 阿蘇火砕 流堆積物

図一7 熊本平野西部の地下水首図 ${ }^{12)}$ (図一6 の $\mathrm{AA}^{\prime}$ 断面）

とし，北側は金峰山中腹が境とされ，東側は水前寺〜江 津湖〜井寺を結ぶ線, 西側はおもな地下水層が海底に開 口する有明海の水深 $40 \mathrm{~m}$ の線が境亡されている. した がって，ここでは境界条件として，南側第三系山地およ び北側金峰山中腹を不透水壁 $\mathrm{B}_{4}, \mathrm{~B}_{3}$ とし, 東側境界 $\mathrm{B}_{1}$ には資料 ${ }^{12)}$ からの水頭を与えたが, $\mathrm{cd}$ 間は直線変化さ

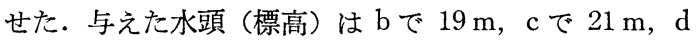
で $7.4 \mathrm{~m}$, e で $8.0 \mathrm{~m}$ である. 西側境界 $\mathrm{B}_{2}$ は水頭 $0 \mathrm{~m}$ を与えた.また，この地域では上層の不圧地下水からの 垂直かん養が考えられている. なお，図一6 の曲線とそ れに記入されている数字は等透水量係数線とその值 ${ }^{12}$ で ある。

(ii) 制御井戸および三角形要素の分割

制御井戸を図一6 の井戸番号 (1) （10）に示寸 10 か 所とした. すなわち, 井戸 1 は城山地区の熊本市水道水 源用井戸, 井戸 2 はこの地区の農業用井戸群を代表する 井戸，井戸 3 は川尻地区の熊本市の上水道水源用井戸群 を代表する井戸，井戸 4，5，9 はこの地区の工業用の井戸群を 3 つの井戸におきかえたもの，

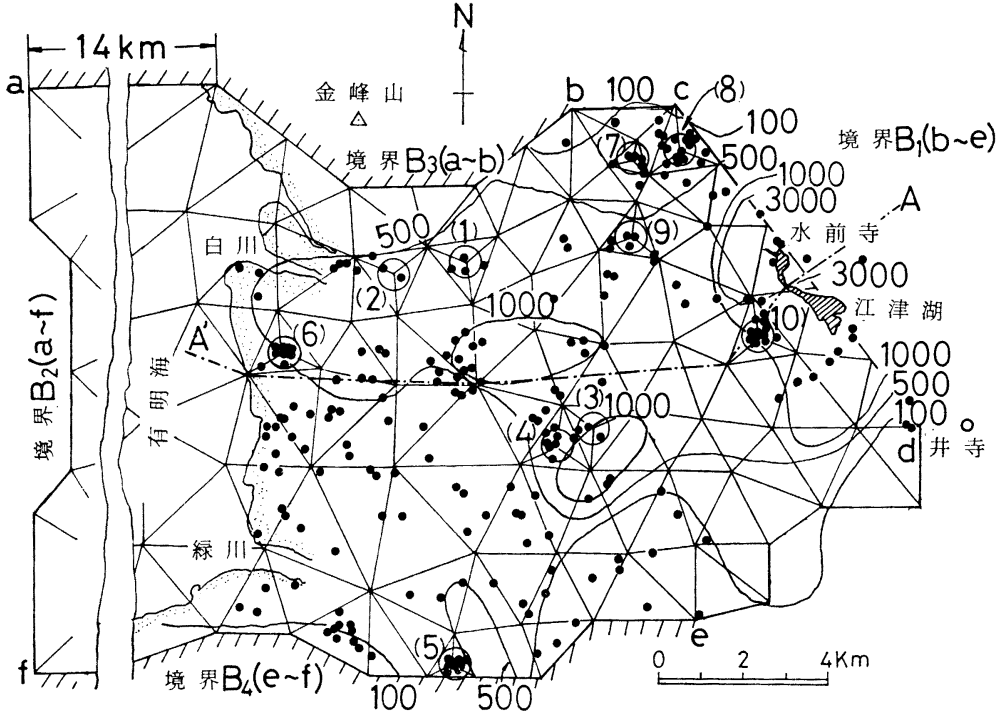

図一6 熊本平野西部被圧地下水領域（図中の（）の数字は制御井戸番号, $100,500, \cdots$ などの数字は透水量係数值 $\left(\mathrm{m}^{2} /\right.$ day $\left.)\right)$
井戸 7,8 はこの地区に集中す るビル用井戸群，井戸 6,10 は この地区の養鰻場用の井戸群を 代表させたものである．以上， 境界条件および制御井戸から 図一6のように領域を三角形要 素に分割した. 三角形要素数は 170 個，節点数は 104 個であ る. なお，各三角形要素の透水 量係数は図中の等透水量係数線 をもとにして与えた。

（iii）非制御井戸および帯水 領域への流出入量

熊本市の報告書 ${ }^{12}$ によると， ここで考えている熊本平野西部 
地域には $30 \mathrm{~m}$ 以深の深井戸が 700 本ほどあるとされて いるがここではこのうち前述の 10 か所の制御井戸と 報告書でその位置と揚水量が示されている井戸146本を 非制御大井戸として，制御井戸と非制御大井戸を図一6 の黒丸で示している.なお，非制御大井戸にはそれぞれ 一定の取水量を与え, この量は制御井戸の取水量によっ て左右されることはないとした.

次に非制御小井戸は位置も揚水量も不明であるので， 前述のように被圧带水層からの平面的に均等な流出量と して取扱い，上層不圧地下水加らの垂直かん養 (流入量) と一緒にして考える.この流出入量は式 (16) の $\boldsymbol{q}$ に 含まれる $\boldsymbol{R}_{1}, \boldsymbol{R}_{2}$ (各節点への配分量) であるが，現時 点では不明であるので一応同報告書の昭和 49 年 9 月の 時点の境界値, 制御井戸と非制御大井戸の既知の揚水量 地域内の水頭分布を式 (12) に与えて $\boldsymbol{R}$ を逆に算出し, この $\boldsymbol{R}$ を以後の取水計画の算定には既知量として節点 に与えることにした。

（iv） 低限界水頭と水需要量

ここでは制御井戸に与える低限界水頭 $\boldsymbol{h}_{\boldsymbol{w}}{ }^{*}$ を一律に 標高 $-5 \mathrm{~m},-3 \mathrm{~m},-1 \mathrm{~m}$ とした. これは井戸 9 地点 （取水前の井戸地点水頭標高 $+4 \mathrm{~m}$ ) を例にとると水頭低 下量 $\Delta h$ が $9 \mathrm{~m}, 7 \mathrm{~m}, 5 \mathrm{~m}$ に相当する. したがって, 井 戸 9 地点での最終圧密沈下量は, 熊本市報告書 ${ }^{12)}$ に述へ ているこの地域での被圧帯水層上部の圧密粘土層厚さ $b^{\prime}=40 \mathrm{~m}$ とその層の体積圧縮係数 $m_{v}=8 \times 10^{-2} \mathrm{~cm}^{2} / \mathrm{kg}$ を用いて式 (17) より算定すると，それぞれ $28.8 \mathrm{~cm}$, $22.4 \mathrm{~cm}, 16.0 \mathrm{~cm}$ となる. この值はかなり大きい值のよ らであるが，一般に深井戸の取水では最大 $5 \sim 20 \mathrm{~m}$ 程

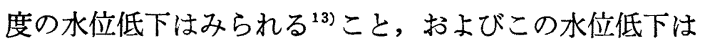

井戸周辺の比較的狭い範囲であり，したがって，ここに 算定された沈下量がそのまま現実の井戸周辺における沈 下として現われるかどうかについては疑問であるので， ここでは一応この $\boldsymbol{h}_{w}{ }^{*}$ を用いることにする.

次に海岸部の制御井戸に対しては塩水の侵入防止の面 からも低限界水頭を設定しなければならない，塩水の侵 入については, 深さが十分大きな不圧地下水層では井戸 水頭が海水面以下になれば終局的には海水は井戸中に侵 入してくる.また，不透水層が有限の深さにある不圧地 下水あるい流有限厚さの被圧地下水層の場合は, 井戸水 位は海水面以下に低下していても井戸と海岸との間に淡 水位の高い部分があって, この淡水圧によって塩水楔の 侵入が停止されることもある．したがって，塩水の侵入 防止の面から設定される低限界水頭は帯水層の形状およ び地質, 海岸から内陸部への淡水の水頭勾配, 海岸と井 戸との距離などにより変わってくると考えられる.さ て, この地域甠有限厚さの被圧地下水層であり, また, 海岸にもっとも近い井戸 6 も水頭 $0 \mathrm{~m}$ を与えた境界 $\mathrm{B}_{2}$ からある程度の距離をもっていることから, 海水面以下 の井戸水位の低下もある程度許容されるものではないか と考えられ, 詳細な検討は今後に待つとして, 本計算の 目的が最適取水の適用例であることもあって，一応ここ では海岸近くの制御井戸にも前述の低限界水頭を一律に 与えることにする.なお, 地盤沈下抢よび塩水侵入防止 の面からの低限界水頭の值については今後研究を要する 重要な事項と考えられる.

次に各制御井戸に課せられる水需要量として 同報告 書 ${ }^{12)}$ であげられている 5 つの揚水計画案の值をとった. これを表一1 に示している.

表一1 水需要量 $\boldsymbol{Q}_{w}{ }^{*}$ (成分 $\left.\boldsymbol{Q}_{m}{ }^{*}\right)$ ( $m$ は制御井厂の番号) (単位 : $10^{4} \mathrm{~m}^{3} /$ day)

\begin{tabular}{|c|c|c|c|c|c|c|c|c|c|c|c|}
\hline$m$ & 1 & 2 & 3 & 4 & 5 & 6 & 7 & 8 & 9 & 10 & $\sum Q_{m}{ }^{*}$ \\
\hline 1 & 1.50 & 0.60 & 1.00 & 0.27 & 0.27 & 0.60 & 0.60 & 0.60 & 0.27 & 0.60 & 6.31 \\
\hline 2 & 3.00 & 0.60 & 2.80 & 0.50 & 0.50 & 0.80 & 0.80 & 0.80 & 0.50 & 0.80 & 11.10 \\
\hline 3 & 2.00 & 2.00 & 1.00 & 1.00 & 1.00 & 1.50 & 1.50 & 1.50 & 1.00 & 1.50 & 14.00 \\
\hline 4 & 3.00 & 1.30 & 2.80 & 0.90 & 0.90 & 1.50 & 1.50 & 1.50 & 0.90 & 1.50 & 15.80 \\
\hline 5 & 3.50 & 1.30 & 3.00 & 1.80 & 1.80 & 2.10 & 2.10 & 2.10 & 1.80 & 2.10 & 21.60 \\
\hline
\end{tabular}

表一2 $\boldsymbol{P}$ (成分 $\left.P_{m l}\right)<\boldsymbol{U}\left(\right.$ 成分 $\left.u_{l}\right)\left(m, l\right.$ は制御井戸の番号, $\left.u_{l}=\sum_{m} P_{m l}\right)$ (単位: $\mathrm{m}^{2} /$ day)

\begin{tabular}{|c|c|c|c|c|c|c|c|c|c|c|c|}
\hline$l$ & 1 & 2 & 3 & 4 & 5 & 6 & 7 & 8 & 9 & 10 & $u_{l}$ \\
\hline 1 & -1640.0 & 752.0 & 193.0 & 159.0 & 17.4 & 110.0 & 41.7 & 4.9 & 254.0 & 33.5 & -74.5 \\
\hline 2 & 752.0 & -1390.0 & 54.0 & 68.3 & 24.9 & 408.0 & 4.5 & 0.5 & 34.9 & 7.0 & -35.5 \\
\hline 3 & 193.0 & 54.4 & -2590.0 & 1540.0 & 53.0 & 38.4 & 9.2 & 1.7 & 177.0 & 245.0 & -278.7 \\
\hline 4 & 159.0 & 68.3 & 1540.0 & -2200.0 & 137.0 & 71.4 & 4.6 & 0.7 & 74.4 & 54.6 & -90.0 \\
\hline 5 & 17.4 & 24.9 & 53.0 & 137.0 & -324.0 & 58.1 & 0.3 & 0.03 & 3.5 & 4.0 & -25.8 \\
\hline 6 & 110.0 & 408.0 & 38.4 & 71.4 & 58.1 & -773.0 & 1.4 & 0.2 & 15.1 & 4.1 & -63.3 \\
\hline 7 & 41.7 & 4.5 & 9.2 & 4.6 & 0.3 & 1.4 & -835.0 & 194.0 & 249.0 & 7.5 & -322.8 \\
\hline 8 & 4.9 & 0.5 & 1.7 & 0.7 & 0.03 & 0.2 & 194.0 & -1090.0 & 115.0 & 3.4 & -769.6 \\
\hline 9 & 254.0 & 34.9 & 177.0 & 74.4 & 3.5 & 15.1 & 249.0 & 115.0 & -1550.0 & 140.0 & -497.1 \\
\hline 10 & 33.5 & 7.0 & 245.0 & 54.6 & 4.0 & 4.1 & 7.5 & 3.4 & 140.0 & -3540.0 & -3040.0 \\
\hline
\end{tabular}


(v) 計算結果および考察

(1) 行列 $\boldsymbol{P}$ (成分 $\left.P_{m l}\right)$

$\boldsymbol{P}$ は式 (15) からわかるように $\boldsymbol{A}$ および $\boldsymbol{F}$ よりな っていて透水量係数，節点および非制御大井戸の座標值 により構成され，式（19）からある制御井戸の水頭が単 位の上昇をしたときの考えている制御井戸の増加水量で ある. すなわち, 表一2 の $\boldsymbol{P}$ の成分 $P_{m l}$ 注制御井戸 $l$ の水頭の単位上昇あたりの制御井戸 $m$ の増加水量であ る. 表一2 の対角成分 $\left(P_{m l}, m=l\right)$ が負であり, その 他 $\left(P_{m l}, m \neq l\right)$ が正であるのは, ある井戸の水量はそ の井戸自身の水頭が低下するほど，また，それ以外の制 御井戸の水頭が上昇するほど大きくなることを示してい る. また，対角成分の絶対值がその他の成分に比べて顕 著に大きいのはその制御井戸の水量にはそれ自身の井戸 の水頭の影響が最も大きいことを示している．また， $P_{m l}$ の大きさは制御井戸 $m, l$ 間が近いほ ぼ，また， $m, l$ 間の透水量係数が大きいほど, すなわち, $m, l$ 間 が流れやすいほど大きい值となっている。

(2) 列ベクトル $\boldsymbol{u}$ (成分 $u_{l}$ )

表一2 に示す $\boldsymbol{u}$ は式 (24) に示すように $P_{m l}$ の $m$ についての合計量で，ある制御井戸 $l$ の水頭が単位上昇 したときのそれ自身の井戸も含めた制御井戸全体の水量 増加の合計を示している. $u_{l}$ の絶対值が大きいことは, 制御井戸 $l$ の水位の変化が全水量に与える影響の大きい ことを示している．また，表一2 に示すように ulがす べて負であることは，1つの制御井戸の水頭が上昇すれ ば，全水量は常に減少することを示していて，したがっ て, 領域内の取水量を大きくするには, 各制御井戸とも 水頭を下げるほどよいことになる．したがって，低限界 水頭以上の条件のもとでの領域の可能な最大取水は各制 御井戸の水頭がすべてその低限界水頭 になったとき

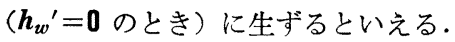

(3) 列ベクトル $\boldsymbol{P}_{0}$ (成分 $\left.P_{0 m}\right)$

$\boldsymbol{P}_{0}$ 注式 (20) に示すように $\boldsymbol{h}_{\boldsymbol{w}}{ }^{*}$ と $\boldsymbol{P}$ および $\boldsymbol{q}$ よ りなり, したがって, 式 (15), (16) から $\boldsymbol{h}_{w}$ と $\boldsymbol{A}$, $\boldsymbol{F}, \boldsymbol{Q}_{r}, \boldsymbol{h}_{b}, \boldsymbol{R}$ よりなりたっている. すなわち, 低限界 水頭と透水量係数, 節点 お. よび 非制御大井戸地点の座 標, 境界条件, 非制御大井戸の揚水量, 被圧水層功の 流出入量から構成されている. $\boldsymbol{P}_{0}$ (成分值 $P_{0 m}$ ) は式 (19) から $\boldsymbol{h}_{\boldsymbol{w}}{ }^{\prime}=\mathbf{0}$ のとき, すなわちその領域の最大取 水時における各制御井戸の取水量であり, $\sum_{m} P_{0 m}=G$ は
その領域の制御井戸による可能な最大取水量である. $P_{0 m}$ および $G$ の值を 表一3 に示している. $P_{0 m}$ は水源 (境界 $\mathrm{B}_{1}, \mathrm{~B}_{2}$ ) に近く, 水源の水頭が高く, 透水量係数 が大で，また， $\boldsymbol{h}_{w}{ }^{*}$ が低いほど大きくなる．また， $P_{0 m}$ の各井戸間の比率は領域の地盤地質の状態掞よび地下水 の賦存状態からもっとも無理のない取水の比率を示して いると考えられ各制御井戸の取水計画をきめる場合の参 考とすべき值と考えられる.

(4) 制御井戸の算定取水量

設定された低限界水頭以上で，また，与えられた水需 要量を満足する 2 条件のもとに領域の総取水量を最大に する解を模式図図一8 について考えてみよう。いま, 制 御井戸 1 4 の $P_{0 m}$ および $Q_{m}{ }^{*}$ が 図一8 のようであ るとする. $P_{0 m}$ の取水時の井戸水頭 $h_{p m}{ }^{\prime}$ 汢図のように 低限界水頭 $h_{m}{ }^{* \prime}=0$ に等しくなる. まず，(1)すべての 井戸で $Q_{m}{ }^{*}$ が $P_{0 m}$ より小であれば上記の 2 条件を満 足する解としての各井戸の取水量は $P_{0 m}$ となり，この ときの井戸水頭は低限界水頭に一致する.

次に図のように $P_{0 m}$ より $Q_{m}{ }^{*}$ が大になる井戸 1,2 がある場合を考える、 いま, 各井戸を $P_{0 m}$ の取水状態 から, $\boldsymbol{h}_{w}{ }^{\prime} \geqq \mathbf{0}$, 取水量 $Q_{m} \geqq Q_{m}{ }^{*}$ の 2 条件を満たす 状態に至る過程を考えると, まず井戸 1,2 の取水量を その $Q_{m}{ }^{*}$ 以上に上げるためには井戸 1,2 の水頭がす でに低限界水頭になっていて，これを下げることはでき

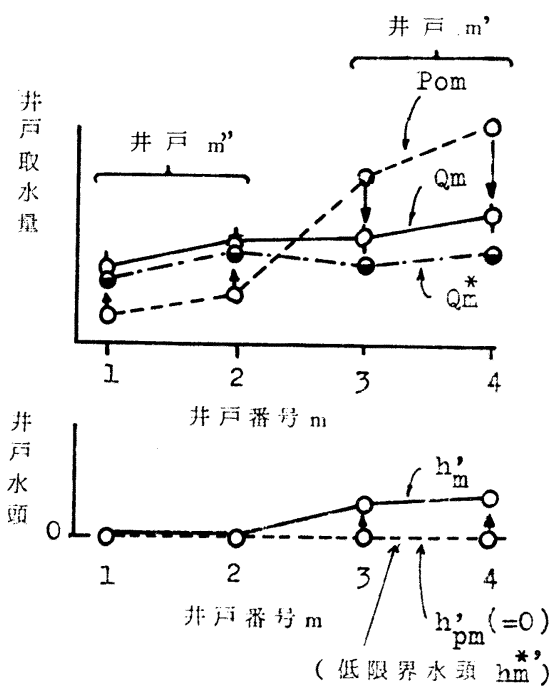

図一8２条件を㴖たし，総取水量最大の解の説明図 表-3 $\boldsymbol{P}_{0}$ (成分 $\left.P_{0 m}\right)$ と $G\left(m\right.$ 注制御井戸の番号, $\boldsymbol{h}_{w}{ }^{*}$ は標高, $\left.G=\sum_{m} P_{0 m}\right)$ (単位: $10^{4} \mathrm{~m}^{3} /$ day)

\begin{tabular}{|c|c|c|c|c|c|c|c|c|c|c|c|}
\hline $\boldsymbol{h}_{w^{*}} m$ & 1 & 2 & 3 & 4 & 5 & 6 & 7 & 8 & 9 & 10 & $G$ \\
\hline$-5 m$ & 1.94 & 1.74 & 1.37 & 1.03 & 0.92 & 1.38 & 1.78 & 2.16 & 1.76 & 4.61 & 18.69 \\
\hline$-3 m$ & 1.92 & 1.73 & 1.31 & 1.01 & 0.91 & 1.37 & 1.72 & 2.01 & 1.67 & 4.00 & 17.65 \\
\hline$-1 \mathrm{~m}$ & 1.91 & 1.72 & 1.26 & 0.99 & 0.91 & 1.36 & 1.65 & 1.86 & 1.57 & 3.39 & 16.62 \\
\hline
\end{tabular}


ないので井戸 3,4 の水頭を上げねばならない.こうす れば井戸 3,4 の取水量が下がる. しかし，この取水量 が $Q_{m}{ }^{*}$ より下がらなければ, 上記の 2 条件を満たす解 として図の実線のような取水量 $Q_{m}$ と井戸水頭 $h_{m}{ }^{\prime}$ が えられる. そうして, (iil)この解のうちで総取水量最大 の状態を求めれば, これがここで求める最適解となる. なお,この場合表一2で述べたように $\left|P_{m l}\right|_{m=l}$ は $\left|P_{m l}\right|_{m \neq l}$ よりかなり大きいため井戸 1,2 を $Q_{m}$ *にも ってくるためには井戸 $3 ， 4$ の水頭をかなり上げねばな らず，そのための井戸 3,4 の水量の減少は井戸 1,2 の $Q_{m} *$ までの水量の増加に比べてかなり大きくなる. し たがって, 領域の総取水量は $\sum_{m} P_{0 m}$ より減少する.す なわち, $P_{0 m}$ に比べて $Q_{m}{ }^{*}$ が大きい井戸が存在する と, いわゆる無理をした取水となり, 地域の総取水量は 減少してゆくことがわかる. 次に, 田井戸 1,2 の $\left(Q_{m}{ }^{*}-P_{0 m}\right)$ がかなり大きいとき，または $\left(Q_{m} *-P_{0 m}\right)$ が小さくとも井戸 3,4 の余裕量 $\left(P_{0 m}-Q_{m} *\right)$ が小さい ときには図一8 の井戸 3,4 の水頭を上げ, 井戸 3,4 の取水量を $Q_{m}$ * まで下げても, 井戸 1,2 の取水量を その $Q_{m}{ }^{*}$ まで上げることができない場合，才なわち上 記の 2 条件を満足する解が得られない場合も生ずる.こ の場合は線形計画法では解は求まらない，なお，すべて の井戸が $Q_{m} *$ の取水をしたとき各水頭が低限界水頭以 上となるかどうかの判定，すなわち各井戸が $Q_{m}{ }^{*}$ で取 水可能かどうかの判定は, 上述のように線形計画法での 解が得られるかどうかでわかるが, 式 (12) の初めの 2 式から $\mathbf{Q}_{w}=\mathbf{Q}_{w}{ }^{*}$ を与えて $\boldsymbol{h}_{w}$ を求め, これが低限界水 頭以上であるかどうかで判定することもできよう。

さて, 表一 4 婊一 1 の水需要量 $Q_{m} *$ のもとに, 低 限界水頭 $-5 \mathrm{~m},-3 \mathrm{~m},-1 \mathrm{~m}$ に対して地域の総取水量 を最大にする各井戸の取水量の算定結果であり，また， 低限界水頭 $-5 \mathrm{~m}$ の場合を 図一-9 13 に例示している. なお，図一12，13 は2 条件を満たす解 $Q_{m}$ が得られな かったが，参考までに $P_{0 m} ， Q_{m}$ *を示しておく。これ らの図について, 上述の説明の (1) (iiii)の場合と対比す ると case 1 は (1) の場合, case 2,3 は (ii) の場合, case 4,5 は (iiii) の場合に相当しょう.また, $\boldsymbol{h}_{w}{ }^{*}=-5$ $\mathrm{m}$, case 1 の場合の最適状態における算定水頭分布図を 図一14 に示している. 次に表一4の $\boldsymbol{h}_{w}{ }^{*}=-5 \mathrm{~m}$ 欄 の $\sum_{m} Q_{m}$ をみると, すべての井戸で $Q_{m}{ }^{*}$ が $P_{0 m}$ より小 さい case 1 の場合はその地域の可能な最大総取水量を

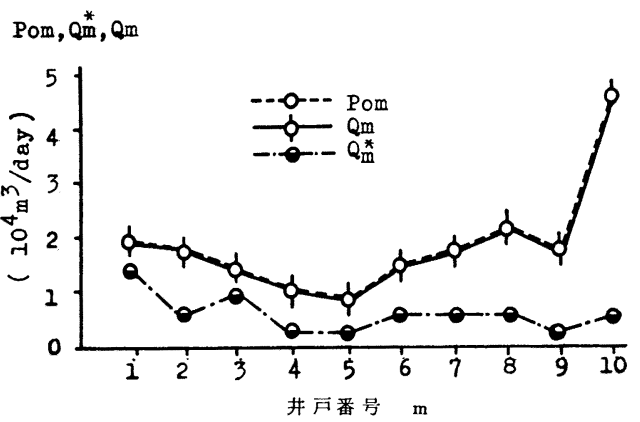

図一9 表-4 の $h_{w}{ }^{*}=-5 \mathrm{~m}$, case 1 の図

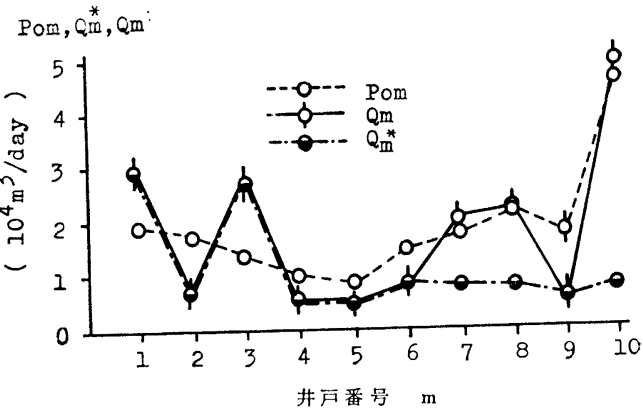

図-10 表-4 の $h_{w}{ }^{*}=-5 \mathrm{~m}$, case 2 の図

Pom, Qm $\stackrel{*}{m}$ m

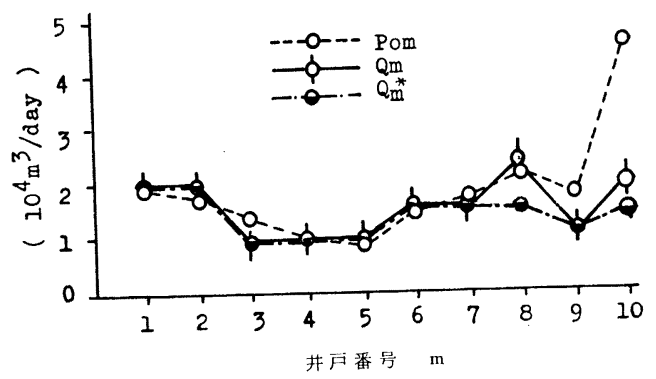

図-11 表-4 の $h_{w}{ }^{*}=-5 \mathrm{~m}$, case 3 の図

表一4 2 条件を滿たし, 総取水量最大の解の算定の $Q_{n}\left(m\right.$ は制御井戸の番号) （単位 $\left.: 10^{4} \mathrm{~m}^{3} / \mathrm{day}\right)$

\begin{tabular}{|c|c|c|c|c|c|c|c|c|c|c|c|c|}
\hline $\boldsymbol{h}_{w}{ }^{*}$ & case $m$ & 1 & 2 & 3 & 4 & 5 & 6 & 7 & 8 & 9 & 10 & $\sum Q_{m}$ \\
\hline \multirow{3}{*}{$-5 m$} & 1 & 1.94 & 1.74 & 1.37 & 1.03 & 0.92 & 1.38 & 1.78 & 2.16 & 1.76 & 4.61 & 18.69 \\
\hline & 2 & 3.00 & 0.60 & 2.80 & 0.50 & 0.50 & 0.80 & 2.03 & 2.29 & 0.50 & 4.83 & 17.85 \\
\hline & 3 & 2.00 & 2.00 & 1.00 & 1.00 & 1.00 & 1.50 & 1.50 & 2.38 & 1.00 & 2.00 & 15.38 \\
\hline \multirow{2}{*}{$-3 \mathrm{~m}$} & 1 & 1.92 & 1.73 & 1.31 & 1.01 & 0.91 & 1.37 & 1.72 & 2.01 & 1.67 & 4.00 & 17.65 \\
\hline & 2 & 3.00 & 0.60 & 2.80 & 0.50 & 0.50 & 0.80 & 1.04 & 2.38 & 0.50 & 4.25 & 16.37 \\
\hline \multirow{2}{*}{$-1 \mathrm{~m}$} & 1 & 1.91 & 1.72 & 1.26 & 0.99 & 0.91 & 1.36 & 1.65 & 1.86 & 1.57 & 3.39 & 16.62 \\
\hline & 2 & 3.00 & 0.60 & 2.80 & 0.50 & 0.50 & 0.80 & 0.80 & 2.26 & 0.50 & 2.67 & 14.43 \\
\hline
\end{tabular}

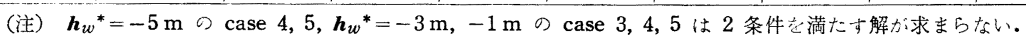




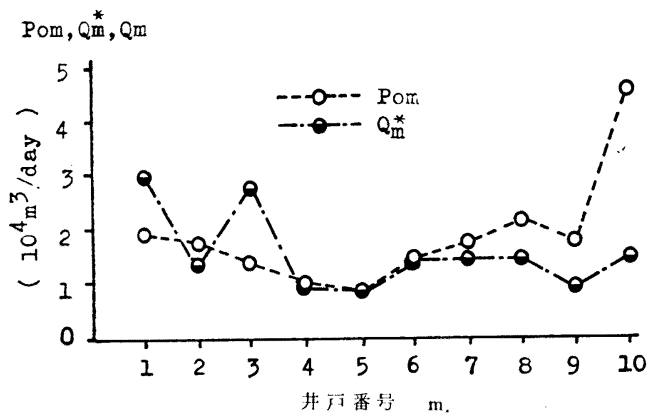

図-12 表-4 の $\boldsymbol{h}_{w}{ }^{*}=-5 \mathrm{~m}$, case 4 の図 $\left(Q_{m}\right.$ は求まらない)

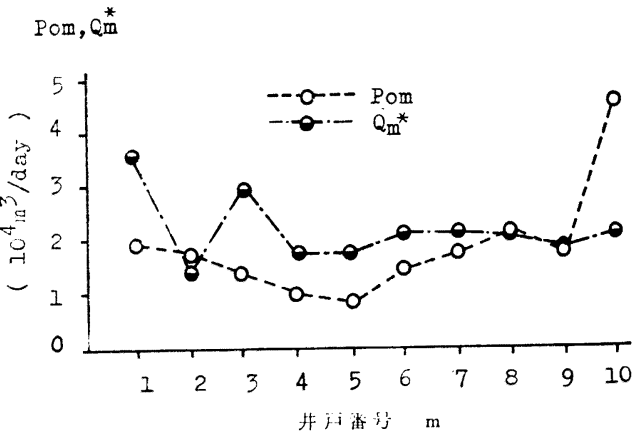

図一13 表-4 の $\boldsymbol{h}_{w}{ }^{*}=-5 \mathrm{~m}$, case 5 の図 $\left(Q_{m}\right.$ は求まらない)

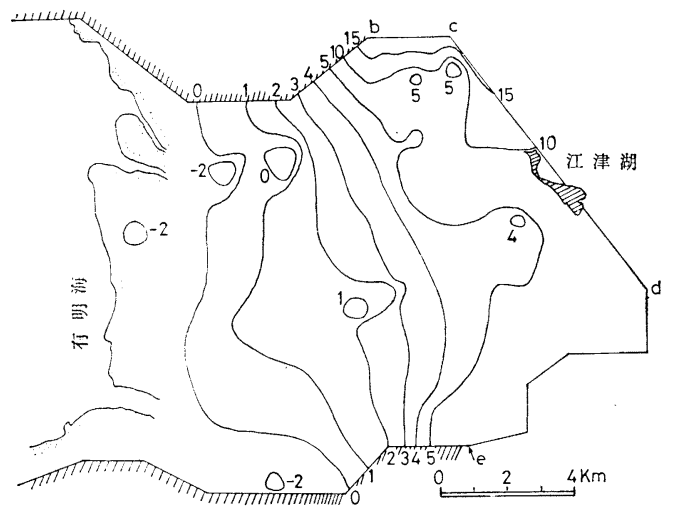

図-14 表-4 の $\boldsymbol{h}_{w}{ }^{*}=-5 \mathrm{~m}$, case 1 の水頭分布図 (図の数字は水頭 $\mathrm{h}$ （標高 $\mathrm{m}$ ) $b \sim e$ などは 図一6 に示すもの)

示し, $Q_{m} *$ が $P_{0 m}$ より大きい井戸が生じてくると, case 2,3 のように総取水量は減少し, さらに $Q_{m}$ *に 達しない井戸が生じてくることがわかる．次に低限界水 頭を変えた場合の総取水量をみると, 同じ case につい ては $-5 \mathrm{~m},-3 \mathrm{~m},-1 \mathrm{~m}$ の順に総取水量は小さくなる が，低限界水頭が $-5 \mathrm{~m}$ の Case $3,-3 \mathrm{~m}$ の Case 2 の 総取水量は低限界水頭が $-1 \mathrm{~m}$ の Case 1 の総取水量よ りも小さくなっていて，前述のように $Q_{m} *$ が $P_{0 m}$ よ り大きい井戸があると低限界水頭が低くても総取水量が
減少する場合があることがわかる.

\section{（3）低限界水頭以上で水需要量に達しない井戸があ るとき井戸間の地上導水量を最小にする解}

a）基 礎 式

表一4 の闌外に示す case は前述の 3. (2) の計算では 解が得られない.この場合は $Q_{m}<Q_{m} *$ の井戸に対し てその不足分 $Q_{m}{ }^{*}-Q_{m}$ を水需要量より大きくとってよ い余裕のある井戸から地上導水する必要がある.いま, 地域全体での 総需要量が, その地域の取水可能量 $G=$ $\sum_{m} P_{0 m}$ より少ない場合需要は地下水取水のみで充足さ れうるので, 導水距離を一応考虑外にすれば導水費を安 くするという経済的面から考えた最適の取水としては, 低限界水頭以上といら条件のもとに各井戸の水需要量を 丁度 (過不足なく) 達成するための井戸間の地上での導 水量を最小にすることと考えられよう。すなわち, 図一 8 で低限界水頭以上といら条件のもとでは井戸 1,2 の 取水量 $Q_{m}$ をその水需要量 $Q_{m}$ *まで上げることができ ないとき，図一15 の実線のようにして井戸 1，2 の不 足量 $\sum_{m=1,2}\left(Q_{m} *-Q_{m}\right)$ と井戸 3,4 の余裕量 $\sum_{m=3,4}\left(Q_{m}-\right.$ $\left.Q_{m} *\right)$ とが等しくてしかもこの量が最小の状態を求める 問題となる. この場合の各井戸の取水量は次のようにし て決定される.

いま，図一15のように制御井戸 $m$ ，このうち $P_{0 m^{\prime}} \geqq$ $Q_{m^{\prime}}$ * の井戸を $m^{\prime}, P_{0 m^{\prime \prime}}<Q_{m^{\prime \prime}} *$ の井戸を $m^{\prime \prime}$ とす れば, 地上導水量 $g_{d}$ を最小にすることから,

$$
\begin{aligned}
g_{d} & =\sum_{m^{\prime \prime}}\left(Q_{m^{\prime \prime}} *-Q_{m^{\prime \prime}}\right) \\
& =\sum_{m^{\prime \prime}} Q_{m^{\prime \prime}} *-\sum_{m^{\prime \prime}} Q_{m^{\prime \prime}} \Rightarrow \min
\end{aligned}
$$

or

$$
g^{\prime}=\sum_{m^{\prime \prime}} Q_{m^{\prime \prime}} \Rightarrow \max
$$
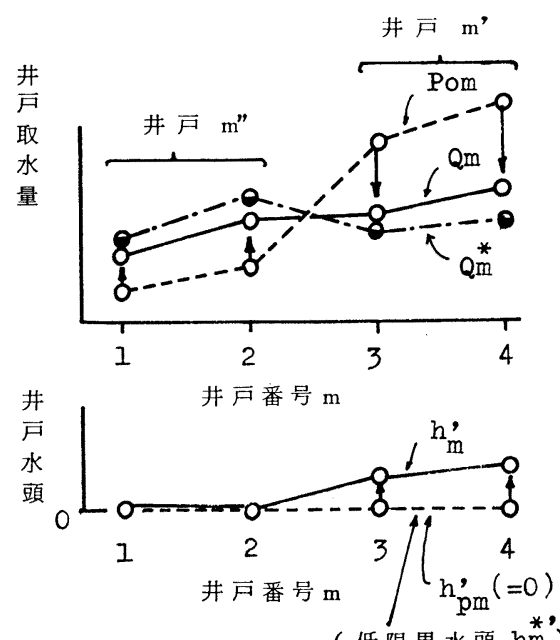

(低限界水頭 $\mathrm{hm}^{*}$ )

図一15 $\boldsymbol{h}_{w^{\prime}}{ }^{\prime} \geqq 0$ を滿たし，地上導水量最小の解の説明図 
表一5 $\boldsymbol{h}_{w}{ }^{\prime} \geqq 0$ を満たし, 地上迸水量最小の解の算定 $Q_{m}\left(\boldsymbol{h}_{w}{ }^{*}=-5 \mathrm{~m}\right.$, case 4 の場合, $m$ は制御井戸の番号 $)$

(単位 : $10^{4} \mathrm{~m}^{3} /$ day)

\begin{tabular}{|c|c|c|c|c|c|c|c|c|c|c|c|}
\hline$Q{ }^{m}$ & 1 & 2 & 3 & 4 & 5 & 6 & 7 & 8 & 9 & 10 & 計 \\
\hline$Q_{m}$ & 2.49 & 1.30 & 1.92 & 0.90 & 0.90 & 1.50 & 1.50 & 2.36 & 0.90 & 2.03 & 15.80 \\
\hline$Q_{m}^{*}$ & 3.00 & 1.30 & 2.80 & 0.90 & 0.90 & 1.50 & 1.50 & 1.50 & 0.90 & 1.50 & 15.80 \\
\hline$Q_{m}-Q_{m}^{*}$ & -0.51 & 0 & -0.88 & 0 & 0 & 0 & 0 & +0.86 & 0 & +0.53 & 0 \\
\hline
\end{tabular}

次に地域全体の総需要量が地下水のみでまかなわれる 条件として,

$$
\sum_{m=1}^{M} Q_{m} \geqq \sum_{m=1}^{M} Q_{m} *
$$

井戸 $m^{\prime}$ については,

$$
Q_{m^{\prime}} \geqq Q_{m}{ }^{*}
$$

また，井戸 $m^{\prime \prime}$ については $Q_{m}{ }^{\prime \prime}$ が $Q_{m^{\prime \prime}} *$ より大きく なると式 (26) の $\min$ の意味がなくなるので,

$$
Q_{m^{\prime \prime}} \leqq Q_{m^{\prime \prime}} *
$$

したがって,この場合の各井戸の取水量の算定は $\boldsymbol{h}_{w}{ }^{\prime} \geqq$ $\mathbf{0}$ および式 (27)〜 (29) を制約条件として式（26）を目 的関数とする線形計画問題として解を求めることができ る.

\section{b) 計算結果}

表一4の解が得られない闌外の case を考えると case 3,4 は $\sum Q_{m} *<\sum P_{0 m}$ であるから，ここで考えてい る場合に該当する. いま, case 4 の低限界水頭 $\boldsymbol{h}_{\boldsymbol{w}}{ }^{*}=-$ $5 \mathrm{~m}$ の場合に適用すると表一5, 図一16 となる.この場 合, 井戸 1,3 が水需要量に達しないが他の余裕のある 井戸 8,10 から地上導水により補給して地域の全制御井 戸は需要量を丁度満足するようになっていて, しかも導 水量最小の結果が得られている. その導水量は 1.39 万 $\mathrm{m}^{3} /$ day である.

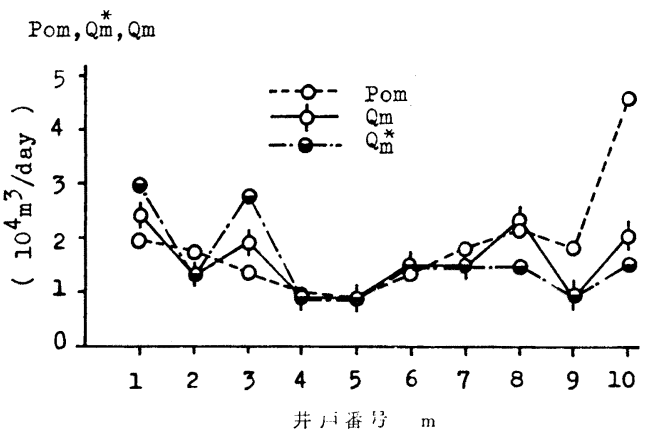

図一16 $h_{w^{\prime}} \geqq 0$ を㴖たし, 地上導水量最小の解 (表一5 の図)

\section{4. 最適取水についての考察}

前述のように各制御井戸はほぼ $P_{0 m}$ の比率で取水す るのがその地域の地質および地下水の状態からいって無
理のない理想的な取水であり，したがって，たとえば人 口, 工場の分散などによって各井戸の水需要量をこの比 率に近づけことは最適取水状態をうる一つの方法と考 えられる.しかし，ここでは，この水需要量は定まって いるものとして低限界水頭以上であることを各井戸の水 需要量を満たすことの条件のもとに種々の場合の最適取 水について総合的に検討してみよう.

（I） $\Sigma Q_{m}{ }^{*} \leqq \sum_{m} P_{0 m}$ の場合：この上きは地域内の 井戸取水のみで地域内の総需要量をまかなうことができ る.

(1) すべての制御井戸で, $Q_{m}{ }^{*} \leqq P_{0 m}$ の場合

この場合は各井戸とも $Q_{m}$ *で取水してよく,井戸水位 は低限界水頭以上となり十分安全な取水となる. 次に, この地域外にできるだけ多く送水する必要があるときな どのように, 前述の 2 条件をみたしたうえでこの地域か らできるだけ多く取水したいときは, 各井戸は $P_{0 m}$ で 取水すればよい，この場合の井戸水位はすべて低限界水 頭に一致し, 送水などに使われる余裕量は $\sum_{m}\left(P_{0 m}-\right.$ $\left.Q_{m}^{*}\right)$ である.

(2) $Q_{m^{\prime \prime}} *>P_{0 m^{\prime \prime}}$ の井戸 $m^{\prime \prime}$ が存在する場合 (図一 8, 15 参照)

(a) $\boldsymbol{h}_{w}{ }^{\prime} \geqq \mathbf{0}$ の条件下で, すべての井戸が $Q_{m}$ *で 取水可能の場合

この判定は式 (12)において, $\boldsymbol{Q}_{w}=\boldsymbol{Q}_{u}$ *（成分值 $Q_{m}{ }^{*}$ ) として井戸水位 $\boldsymbol{h}_{\boldsymbol{w}}$ を算定し, これが井戸の低限界水頭 を下がらなければ， $Q_{m}$ * で取水可能となる，なお，前 述 3. (2) の計算プログラムがあるなど, すでにその計算 準備が整っている場合は，3.(2) によって解が得られる かどらかで判定してもよい. 次に上述の 2 条件を満たし たうえで，その地域からできるだけ多く取水したいとき は前述 3. (2) の方法により, 各井戸の取水量 $Q_{m}$ を求め ればよい.この場合の余裕量は $\sum_{m}\left(Q_{m}-Q_{m}{ }^{*}\right)$ となる. また，上述の 2 条件を満たしたうえで，ある特定の制御 井戸（複数でもよい）の取水量をできるだけ大きくした いときも同様の計算で求められる.

（b） $\boldsymbol{h}_{w}{ }^{\prime} \geqq \mathbf{0}$ の条件下で $Q_{m}$ * の取水不可能な井戸 が生じる場合

この判定は前項の（a）に準じて行える.この場合㳉 前述 3. (3) の場合となり, 経済的面から地上導水量最小 
の条件で各井戸の取水量を求める。なお，この場合は地 上導水も含めて各井戸の $Q_{m}{ }^{*}$ 沙確保される. 次に領域 からできるだけ多く取水したい場合は， $P_{0 m}$ で取水し域 内導水して各井戸の $Q_{m}$ *を確保寸れば，その残量（余 裕量)は $\sum_{m}\left(P_{0 m}-Q_{m}{ }^{*}\right)$ となる。

(II) $\sum_{m}^{m} Q_{m} *>\sum_{m} P_{0 m}$ の場合：このときは域内の井 戸取水のみで域内の総需要量をまかなうことができな い.この場合は $P_{0 m}$ で取水して $P_{0 m}>Q_{m}$ *の井戸の 余水 $P_{0 m}-Q_{m}$ * を域内の $Q_{m}$ * に達しない井戸に導水 補給し, さらに $Q_{m}{ }^{*}$ に対し不足の井戸には他地域また は域内の他水源から導水することになる。

\section{5. むすび}

本報は対象とする広域の地下水領域内に分散配置され た取水制御の対象井戸の最適定常取水について検討した ものである. 取水の最適性については, 種々の考え方が あると考えられるが，ここでは各制御井戸の水位が地盤 沈下および地下水の塩水化の防止面から設定された井戸 水位低下の限界值（低限界水頭）以上の水頭をもつこと と, 各制御井戸に課せられた水需要量を満たすことの 2 条件のもとに種々の場合についての最適取水を検討し た. 特に上述の 2 条件を満たす範囲で領域の総取水量ま たは特定の制御井戸の取水量を最大にする解および低限 界水頭以上の条件下では水需要量に達しない制御井戸が ある場合その不足分を他の制御井戸からの地上導水によ るときの導水量最小の解については線形計画法によって 求められ, これらの解について実際の地域として選んだ 熊本平野西部の地下水領域に適用して算定を行ってみ た。この地域については資料がまだ不備で, また, 低限 界水頭の值については不明確であるので, 本計算結果が そのまま実際に利用できるものではないにしても，一応 種々の観点からみた最適取水計画を求めうることがわか ったものと考える.

次に，本報では有限要素法を用いて各制御井戸の水頭 から取水量を求める式形 [式 (14) または式 (19)] を示 したが，この式によって取水計画にあたっての基礎的資
料と考えられる $\boldsymbol{P}, \boldsymbol{P}_{0}$ を取り出すことができたと考え る. ここに, $\boldsymbol{P}$ と $\boldsymbol{P}_{0}$ は式中の係数行列と列ベクトルで あり, 式 (15)，(16）および式（20）で算定されるもの で, 地下水領域の境界条件, 地盤地質の状況, 井戸の大 きさと配置などの関数であって, その領域の地下水揚水 に関する特性量を示すものである.なお地盤沈下や地下 水の塩水化の防止面から設定される低限界水頭は今後検 討を要する重要な值と考えられる.

謝辞 : 本研究を行うにあたり, 熊本市水道局の方 々および九州農政局の粐倉克幹地質官より多くの御助言 をいただきました。また，本学卒業生 緒方博史君（現 在 (株) 日本道路勤務) および内田 寿君 (現在 大分 市役所勤務）には資料整理に御協力を得ました。ここに 感謝いたします.

参 考 文 献

1) Eduardo Aguado and Irwin Remson : Ground-Water Hydraulics In Aquifer Management, ASCE, Vol. 100, HY-1, pp. 103-118, Jan., 1974.

2) Eduardo Aguado, Irwin Remson, Mary F. Pikul, and Will A. Thomas : Optimal Pumping For Aquifer Dewatering, ASCE, Vol. 100, HY 7, pp, 869-877, July, 1974.

3) Eduardo Aguado, Nicholas S, and Irwin Remson : Sensitivity Analysis in Aquifer Studies, Jour. of Geophysical Research, Vol. 13, No. 4, pp. 733-737, Aug., 1977.

4）佐藤邦明・渡辺邦夫：地下水の適正揚水システム化に関 する研究, 水資源に関するシンポジウム前刷集, pp. 429434, 1977.

5）佐藤邦明：地下ダムの貯留機能と制御・管理システムの 研究, 文部省特定研究報告書 (昭和 51 年度).

6）佐藤邦明：地下ダムの貯留機能と制御・管理システムの 研究, 文部省特定研究報告書 (昭和 52 年度).

7） O.C. ツィェンキーヴィッツ: マトリックス有限要素法, 培風館, 1971 .

8）寺沢宽一：数学概論応用編, 岩波書店, p. 66, 1970.

9）水道施設設計指針 - 解説, 日本水道協会, p. 95, 1977.

10）水収支研究グループ, 柴崎達雄編 : 地下水盈の管理, 東 海大学出版会, pp. $47 \sim 75,1976$.

11）例えば石井吾郎: 数理計画法入門, サイエンス社, 1976.

12）熊本平野低地帯の地下水事情, 熊本市水道局, 1975.

13） 土木工学ハンドブック, p. 1690, 1964.

(1978.4.24 - 受付) 